\title{
Leukemia Inhibitory Factor Is Expressed in Cartilage and Synovium and Can Contribute to the Pathogenesis of Arthritis
}

\author{
Martin Lotz, Thomas Moats, and Peter M. Villiger \\ Sam and Rose Stein Institute for Research in Aging and Department of Medicine, \\ University of California, San Diego, La Jolla, California 92093
}

\section{Abstract}

This study reports on leukemia inhibitory factor (LIF) in human articular connective tissues. Biologically active LIF is present in synovial fluids from patients with osteoarthritis and at higher titers in samples from patients with rheumatoid arthritis. Cultured human synoviocytes and articular chondrocytes produced biologically active LIF and synthesized and secreted LIF proteins that migrated in SDS PAGE at $\sim 43 \mathrm{kD}$. This was increased after stimulation with IL-1 $\beta$.

Chondrocytes in serum-containing cultures expressed the 4.2-kb LIF mRNA. IL-1 $\beta$, LPS, and to a lesser extent tumor necrosis factor- $\alpha$ induced LIF gene expression. LIF autoinduced its mRNA and this provides evidence for an effect of this cytokine on function of joint tissue cells. Among a series of growth factors tested, transforming growth factor (TGF $\beta$ ), including the isoforms TGF- $\beta_{1}$, TGF- $\beta_{2}$, and TGF- $\beta_{3}$, plateletderived growth factor, basic fibroblast growth factor, and insulin-like growth factor induced this cytokine gene but differed with respect to the duration of their effects. Cultured synoviocytes expressed the LIF gene in response to the same set of peptide regulatory factors. Analysis of signal transduction pathways showed that PMA increased LIF mRNA, whereas calcium ionophore and cAMP had no detectable effects. Cycloheximide was a potent LIF mRNA inducer and dexamethasone inhibited LIF induced by PMA or IL-1 $\beta$. Cartilage organ cultures and synovial tissues stimulated with IL-1 expressed high levels of LIF mRNA as demonstrated by in situ hybridization.

These results identify LIF as a new cytokine that is produced by joint tissue cells and is overexpressed in arthritis. The induction of this cytokine by factors that are present during joint inflammation and the effects of LIF on connective tissue cells suggest that LIF is a mediator that can contribute to the pathogenesis of arthritis. ( J. Clin. Invest. 1992. 90:888-896.) Key words: chondrocytes - synoviocytes • leukemia inhibitory factor $\bullet$ arthritis

\section{Introduction}

Cytokines are developmental and homeostatic regulators of joint tissue cells and pathogenetic mediators of connective tis-

Address reprint requests to Dr. Lotz, Stein Institute for Research in Aging, Department of Medicine, University of California, San Diego, La Jolla, CA 92093.

Received for publication 13 January 1992 and in revised form 14 April 1992.

J. Clin. Invest.

(c) The American Society for Clinical Investigation, Inc.

$0021-9738 / 92 / 09 / 0888 / 09 \$ 2.00$

Volume 90, September 1992, 888-896 sue destruction in arthritis. IL-1 and (TNF) ${ }^{1}$ are known as important catabolic factors that induce the production of proteases and $\mathrm{PGE}_{2}$ and inhibit the formation of extracellular martix components (1-4). IL-6 (reviewed in reference 5) which is induced by IL- 1 and TNF does not induce the production of proteases but rather stimulates the synthesis of protease inhibitors by connective tissue cells $(6)$ and hepatocytes $(7,8)$. In addition, IL-6 is a stimulator of chondrocyte proliferation (9). A separate group of cytokines, referred to as intercrines contains chemotactic factors for monocytes, lymphocytes and neutrophils ( reviewed in reference 10). Most of these cytokines are produced by synovium and chondrocytes and can be found in synovial effusions at higher titers usually in more inflammatory arthropathies (11-19).

Leukemia inhibitory factor (LIF; reviewed in references 20 and 21 ) is a cytokine that was characterized on the basis of its ability to induce differentiation of murine myeloid leukemia cells (22-24). Other important effects on hematopoietic cells include the stimulation of bone marrow blasts and of megakaryocytes $(25,26)$. LIF has been shown to inhibit differentiation of embryonic stem cells (27), to promote the generation of sensory (28) and cholinergic (29) neurons, and to stimulate a set of hepatic acute phase proteins that is similar to that induced by IL-6 (30). LIF shares with TNF the ability to inhibit the expression of lipoprotein lipase (31).

First evidence in support of a role of LIF in connective tissue metabolism was obtained from studies on bone where the overexpression of LIF resulted in the accumulation of excess osteoblasts in the marrow and new bone formation (32, 33). In neonatal mouse calvaria LIF stimulated bone resorption in a $\mathrm{PGE}_{2}$-dependent mechanism and an increase in the number of osteoclasts (34). LIF appears to stimulate osteoblasts directly and it induces the expression of alkaline phosphatase. LIF activation of osteoclasts probably results from the indirect activation of osteoclasts by osteoblasts, since only the latter express LIF receptors (35-37).

No information is available on the expression of LIF by joint tissue cells and potential effects on their function. This study reports on the presence of LIF in synovial fluids, the regulation of LIF production by human articular chondrocytes and synoviocytes and its expression in cartilage and synovium.

\section{Methods}

Chondrocyte isolation and culture. Cartilage was obtained at autopsy from donors without known history of joint disease. For all experi-

1. Abbreviations used in this paper: $\mathrm{bFGF}$, basic fibroblast growth factor; LIF, leukemia inhibitory factor; OA, osteoarthritis; PCR, polymerase chain reaction; PDGF, platelet-derived growth factor; RA, rheumatoid arthritis; TGF, transforming growth factor; TNF, tumor necrosis factor. 
ments reported here, cartilage from the femoral condyles and tibial plateaus of the knee joints was used. At autopsy, cartilage slices were prepared and washed with DME (Whittaker Bioproducts, Walkerville, MD). Cartilage was minced with a scalpel and treated with trypsin ( $10 \% \mathrm{vol} / \mathrm{vol}$ ) for $15 \mathrm{~min}$ in a $37^{\circ} \mathrm{C}$ waterbath. The samples were transferred to DME containing $5 \% \mathrm{FBS}$, penicillin-streptomycin-fungizone, and $2 \mathrm{mg} / \mathrm{ml}$ clostridial collagenase type IV (Sigma Chemical Co., St. Louis, MO) and digested for $3 \mathrm{~h}$ on a gyratory shaker until the tissue fragments were dissolved. The cells were washed three times and cultured as primary chondrocytes. Chondrocytes from different donors were always cultured separately and each experiment was performed with replicate flasks of chondrocyte cultures from the same donor.

Where indicated, subcultured cells ( passages 1-8) were trypsinized from T175 flasks and plated in 96-well plates at 5.000-20.000 cells per well in DME $1 \%$ FBS. The media was removed, the wells were washed twice with serum-free DME and culture was continued in DME supplemented with L-glutamine and antibiotics.

Primary chondrocytes were cultured in T175 flasks for $24 \mathrm{~h}$ after isolation from cartilage in DME 5\% FBS. The cells were nonadherent at that time point. They were collected, washed twice in serum-free media and plated in serum-free media as described above. For cartilage organ culture experiments, slices of normal knee cartilage $(\sim 0.8 \times 0.5$ $\times 0.2 \mathrm{~cm}$ ) were prepared, weighed, and cultured in 12-well plates.

Synoviocyte isolation and culture. Synovial tissues were obtained at autopsy from donors without known history of joint disease or at the time of total hip or knee replacement from patients with rheumatoid arthritis (RA) or osteoarthritis (OA). The tissues were minced with a scalpel and treated with trypsin $(10 \% \mathrm{vol} / \mathrm{vol})$ for $15 \mathrm{~min}$ in a $37^{\circ} \mathrm{C}$ waterbath. The samples were transferred to DME containing $5 \%$ FBS, penicillin-streptomycin-fungizone and $2 \mathrm{mg} / \mathrm{ml}$ clostridial collagenase type IV (Sigma Chemical Co.) and digested for $3 \mathrm{~h}$ on a gyratory shaker until the tissue fragments were digested. The cells were washed three times and the adherent cells were cultured as primary synoviocytes.

Synovial fluids. Synovial fluids (all from knee joints) were obtained from five patients with seropositive RA and five patients with OA. All patients with RA were on remittive therapy and nonsteroidal anti-inflammatory drugs. Three patients received low-dose oral prednisone. The OA patients were on nonsteroidal anti-inflammatory drugs. None of the patients received intraarticular steroid injections for at least 3 mo into the same knee from which the sample was taken. Synovial fluids were processed as described earlier (15).

Metabolic labeling and immunoprecipitation. Synoviocytes or chondrocytes were maintained in T175 flasks in DME containing 10\% FBS, L-glutamine and antibiotics. For metabolic labeling, subcultured cells were plated in 24-well plates at a density of 10.000 cells per well. Before the experiment, cells were serum starved for $24 \mathrm{~h}$ and then washed in PBS. They were incubated in cysteine- and methionine-free RPMI (ICN Biomedicals, Inc., Costa Mesa, CA) supplemented with L-glutamine, penicillin-streptomycin, $1 \% \mathrm{FBS},\left[{ }^{35} \mathrm{~S}\right]$ cysteine and $\left[{ }^{35} \mathrm{~S}\right]-$ methionine (ICN Biomedicals; $100 \mu \mathrm{Ci} / \mathrm{ml}$ ) for $4 \mathrm{~h}$. The supernatants were collected and precleared by incubating with protein $\mathrm{G}$ sepharose (Zymed, Inc., San Francisco, CA) for $1 \mathrm{~h}$. The samples were incubated overnight in the presence of rabbit antibody to recombinant LIF (Peprotech Inc., Rocky Hill, NJ; $2 \mu \mathrm{g}$ per sample) on a rotor, and protein A Sepharose was added for an additional $2 \mathrm{~h}$. The precipitates were washed five times with PBS containing $0.05 \%$ Tween-80, $0.1 \%$ Triton $\mathrm{X}-100$, and $1 \mathrm{mM}$ PMSF followed by two washes in PBS. The beads were boiled for $5 \mathrm{~min}$ in Laemmli sample buffer and the proteins were separated on $12.5 \%$ polyacrylamide gels under reducing conditions. After staining with Coomassie Blue the gels were treated with Amplify (Amersham Corp., Arlington Heights, IL) for $1 \mathrm{~h}$, dried, and exposed to Kodak XAR film (Eastman Kodak Co., Rochester, NY) at $-70^{\circ} \mathrm{C}$ for $24 \mathrm{~h}$.

$R N A$ probe preparation. The LIF probe was generated by polymerase chain reaction (PCR), using genomic DNA from a hepatoma cell line $\left(\mathrm{HepG}_{2}\right)$ as a template. PCR reactions (in a volume of $100 \mu \mathrm{l}$ ) contained $10 \mathrm{mM}$ Tris-Cl, pH 8.3, $50 \mathrm{mM} \mathrm{KCl}, 1.5 \mathrm{mM} \mathrm{MgCl}_{2}, 0.1 \%$ gelatin, $1 \mu \mathrm{g} \mathrm{HepG}_{2}$ genomic DNA, $200 \mu \mathrm{M}$ of each dNTP, $100 \mathrm{pM}$ of each specific primer, 1 unit perfect match enhancer (Stratagene Inc., La Jolla, CA).

The sequence of the specific primers were:

LIF5'-AGGAATTCCCCCTCCCCATCACCСCTGTCAACGCCA,

hybridizing to positions 180-207 of the human LIF gene in exon 2 and

\section{LIF3'-GGGGATCCTGCTAGAAGGCCTGGGCCAACA,}

hybridizing to positions $1391-1414$ in exon 3 . The reactions were heated for $5 \mathrm{~min}$ at $94^{\circ} \mathrm{C}$ to denature the template and 2.5 units of Taq polymerase (Cetus Corp., Emeryville, CA) were added. The reaction conditions were $1 \mathrm{~min}$ at $94^{\circ} \mathrm{C}, 1 \mathrm{~min}$ at $65^{\circ} \mathrm{C}$ for $15 \mathrm{cycles}$, followed by 1 min at $94^{\circ} \mathrm{C}, 2 \mathrm{~min}$ at $65^{\circ} \mathrm{C}$ for 15 cycles, followed by 7 min at $72^{\circ} \mathrm{C}$. $10 \%$ of the PCR reaction was electrophoresed through a $1.0 \%$ agarose gel containing ethidium bromide to visualize the product. The amplified product was $1,234 \mathrm{bp}$ in length, containing half of exon 2 and intron 2 and the entire exon 3. A 243-bp fragment (exon 3) was cut using the BamHI site which had been included in the LIF3 oligonucleotide and a SmaI site at position 1171. This fragment was cloned into the BamHI/SmaI sites of pBluescriptKS. The identity of the clone was determined by dideoxy sequencing, using T7 DNA polymerase.

For development of a probe for $\beta$-actin two 15 -bp oligonucleotides ( 5'-CGTCGTCGACAACGG-3' and 5'-GACCGTAGCACTACC-3') defining a 216-bp fragment of the cDNA were designed. The restriction sites EcoRI and HindIII were added at their 5 ' ends, respectively. After amplification by PCR the fragment was inserted into pGEM-4z (Promega Corp., Madison, WI).

The recombinant plasmids were linearized and transcribed with the T7 or T3 RNA polymerase to obtain antisense and sense probes, respectively. For Northern blotting, the probes were labeled with $\left[{ }^{32} \mathrm{P}\right]$ UTP. (Amersham Corp.) and separated from unincorporated nucleotides by gel filtration (Centri-sep columns, Princeton Separations, Adelphia, $\mathrm{NJ})$. The probes for in situ hybridization were generated in the presence of $\left[{ }^{35} \mathrm{~S}\right]$ UTP. After transcription, the template was digested with DNase and the products were recovered by phenol extraction and ethanol precipitation. The specific activity was $\sim 2 \times 10^{8} \mathrm{dpm} / \mu \mathrm{g}$ template.

Northern blot hybridization. Synoviocytes and chondrocytes were maintained in T175 flasks and stimulated as indicated for each experiment. Total RNA was extracted by the single-step guanidinium thiocyanate-phenol-chloroform method (38). 10-30 $\mu \mathrm{g}$ of total RNA was separated on $1 \%$ formaldehyde gels, blotted onto nylon filters, and crosslinked with UV light for $5 \mathrm{~min}$ on each side. The blots were prehybridized in $50 \%$ formamide, $6 \times$ SSC, $0.5 \%$ SDS, $0.1 \%$ Tween 20 , $100 \mu \mathrm{g}$ of yeast $\mathrm{RNA} / \mathrm{ml}$ for $15 \mathrm{~min}$ at $65^{\circ} \mathrm{C}$. The prehybridization mixture was replaced with fresh solution containing $10^{6} \mathrm{cpm} / \mathrm{ml}$ of probe. Hybridization was performed overnight at $65^{\circ} \mathrm{C}$ and followed by washes in $1 \times \mathrm{SSC}, 0.1 \%$ SDS at room temperature (twice for 30 $\mathrm{min}$ ) and $0.1 \times \mathrm{SSC}, 0.1 \% \mathrm{SDS}$ at $65^{\circ} \mathrm{C}$ (twice for $30 \mathrm{~min}$ ). The damp filters were exposed to Kodak XAR film at $-70^{\circ} \mathrm{C}$ for $2-24 \mathrm{~h}$. To confirm equal RNA load and complete transfer the $18 \mathrm{~S}$ and $28 \mathrm{~S}$ bands were visualized with ethidium bromide on all filters. In addition, RNA load was examined by probing for $\beta$-actin mRNA.

In situ hybridization. Synovial tissues and cartilage organ cultures were snap frozen in dry ice / 2 -methyl-butane and stored at $-70^{\circ} \mathrm{C}$ until use. Frozen sections $(5 \mu \mathrm{m})$ were cut and mounted onto precleaned slides (Fisher Scientific Co., San Francisco, CA). They were fixed in $4 \%$ paraformaldehyde, washed in $1 \times \mathrm{PBS}$, and transferred to $2 \times \mathrm{SSC}$.

Hybridization was performed as described elsewhere (39). In brief, the specimens were acetylated in triethanolamine with acetic anhydride and incubated in glycine buffer. Hybridization was carried out with $10^{5} \mathrm{cpm} / \mu \mathrm{l}$ of probe in $50 \%$ Formamide, $3 \times \mathrm{SSC}, 500 \mu \mathrm{g} / \mathrm{ml}$ yeast tRNA, $1 \mathrm{mg} / \mathrm{ml}$ single-stranded calf thymus DNA, $2 \mathrm{mg} / \mathrm{ml}$ BSA, 10 $\mathrm{mM}$ DTT, and $1 \%$ polyethylene glycol (PEG) overnight at $50^{\circ} \mathrm{C}$. Posthybridization treatment consisted of washes with $2 \times$ SSC, $50 \%$ formamide at $50^{\circ} \mathrm{C}$, incubation with RNase solution, and further washes in $2 \times \mathrm{SSC}$ at $55^{\circ} \mathrm{C}$ and thereafter in $2 \times \mathrm{SSC}$ at room tempera- 
ture. Specimens were dehydrated, air-dried and covered with Kodak NTB nuclear track emulsion (Eastman Kodak Co.) for autoradiography. After exposure for $8 \mathrm{~d}$ at $4^{\circ} \mathrm{C}$, the slides were developed, fixed and counterstained with Giemsa. Cells were considered positive, when there were $>20$ granules over nucleus and cytoplasm. A replicate slide was hybridized with a sense probe of LIF to serve as negative controls for each condition.

Reagents. The following reagents were used: recombinant human transforming growth factor (TGF- $\beta 1$ ) platelet-derived growth factor (PDGF), IL-1 $\beta$, TNF $\alpha$, LIF, IL-6, granulocyte/macrophage colonystimulating factor (GM-CSF), and rabbit antibody to recombinant human LIF (R\&D Systems, Minneapolis, MN); Dexamethasone, PMA, cAMP, Ca ionophore (A23187), and LPS from Salmonella Minnesota (Sigma Chemical Co.).

LIF bioassay. Biological activity of LIF was measured with the factor-dependent human erythroleukemia cell line TF-1. These cells are known to proliferate in response to LIF, GM-CSF, IL-3, and erythropoietin (40). The cell line which was originally described by Kitamura et al. (40) was kindly provided by R\&D Systems (Minneapolis, MN). TF-1 cells were maintained in RPMI 1640 supplemented with $10 \%$ FBS, penicillin-streptomycin, and recombinant human GM-CSF $(1 \mathrm{ng} / \mathrm{ml})$, and split twice per week to $10^{4}$ cells $/ \mathrm{ml}$. For use in the LIF assay the cells were washed three times in RPMI 1640 and 10,000 cells were added per well in 96-well flat-bottom plates in RPMI 5\% FBS. The cells were cultured in the presence of test samples for $48 \mathrm{~h}$ when proliferation was measured by the MTT assay (15). LIF activity in synovial fluids or conditioned media was determined on the basis of a standard curve using recombinant human LIF and by neutralization of the TF-1 cell stimulatory activity in the test samples with a LIF-specific antibody. This antibody does not react with TNF- $\alpha$, TNF- $\beta$, GM-CSF, G-CSF, PDGF-AA, PDGF-BB, TGF- $\alpha$, TGF- $\beta$, basic fibroblast growth factor (bFGF), IL-1, IL-2, IL-3, IL-4, IL-6, IL-7, or IL-8.

\section{Results}

LIF activity in synovial fluid. Synovial fluids from patients with RA or OA were analyzed for their ability to stimulate proliferation of the factor-dependent cell line TF-1. All samples caused an increase in TF-1 proliferation when tested at a 1:10 dilution which gave optimal stimulation. Synovial fluids from patients with rheumatoid arthritis had higher titers of activity than those from patients with osteoarthritis (Fig. 1). To determine the amount of this activity that was due to the presence of LIF, antibody neutralization was performed and this showed that all samples contained LIF (Fig. 1). Incubation of the synovial fluids with preimmune rabbit IgG did not detectably reduce the levels of TF-1 proliferation induced by the synovial fluids (not shown). Complete neutralization of the activity could not be achieved and this is the likely consequence of the presence of GM-CSF (16) as at least one additional factor in synovial fluid that can stimulate proliferation of TF-1 cells. The antibody to LIF did not reduce the effect of GM-CSF in the TF-1 assay (not shown).

Expression of LIF activity by synoviocytes and chondrocytes. The next set of experiments analyzed whether joint tissue cells can produce LIF and contribute to the activity found in synovial fluids. Synoviocytes and articular chondrocytes were stimulated with IL-1 $\beta$ and the conditioned media were tested in the TF-1 assay. Low levels of LIF activity were detected in the conditioned media from cells that were cultured in serumcontaining media and titers increased in response to stimulation with IL-1 $\beta$ (Fig. 2). These results show that activated chondrocytes and synoviocytes can secrete biologically active LIF.

Regulation of LIF gene expression by cultured synoviocytes and chondrocytes by cytokines and growth factors. Synoviocytes and chondrocytes expressed low levels of the 4.2-kb LIF mRNA when cultured in the presence of serum. Serum-starved cells had very low or undetectable levels when analyzed by Northern blotting. In response to serum stimulation the cells reexpressed LIF mRNA (not shown). In subsequent experi-

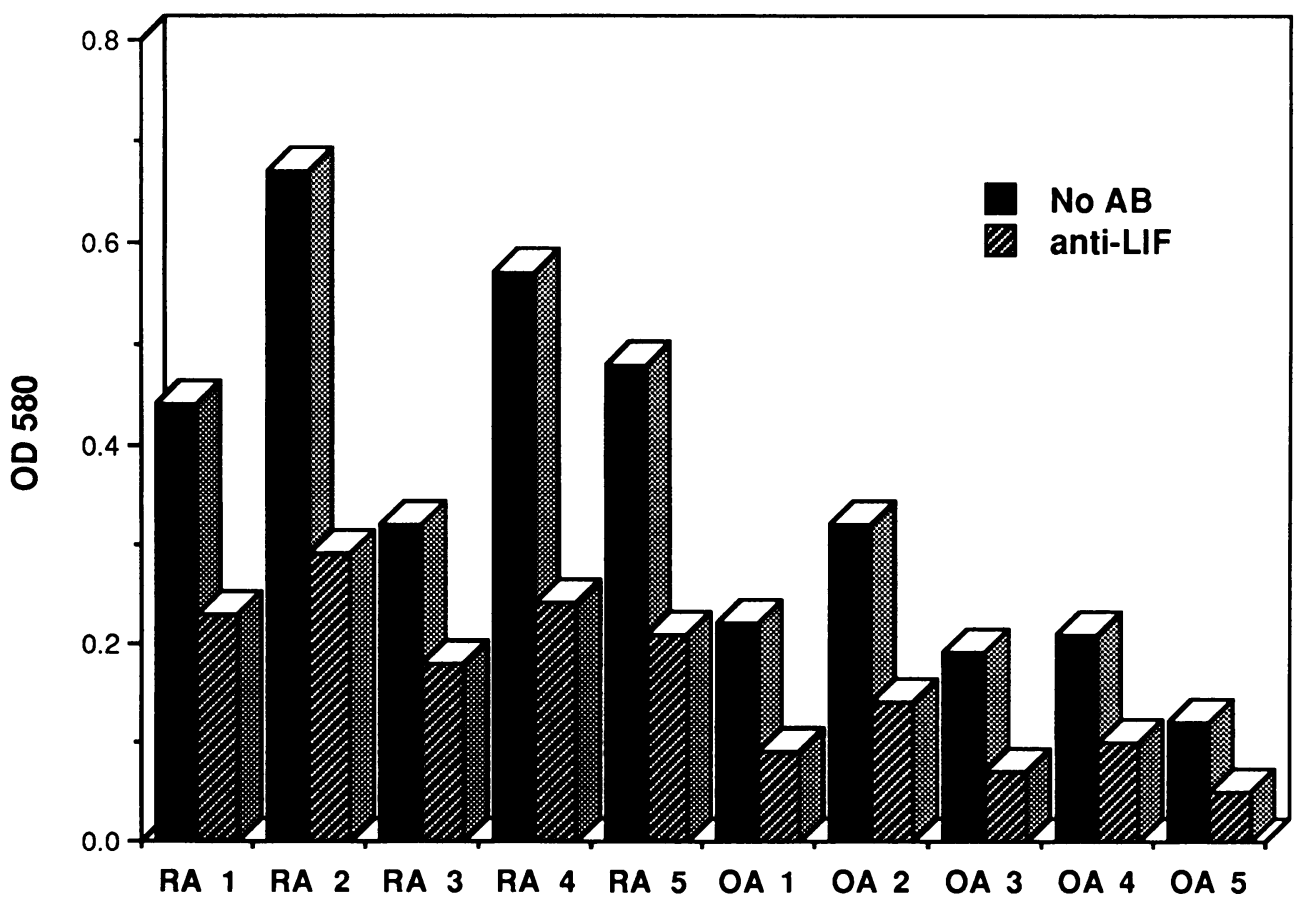

Synovial Fluid
Figure 1. LIF activity in synovial fluids. Synovial fluids from patients with RA or OA were tested in the TF-1 proliferation assay at 1:10 dilutions after preincubation for $2 \mathrm{~h}$ at $37^{\circ} \mathrm{C}$ in the absence or presence of neutralizing antibody to $\operatorname{LIF}(10 \mu \mathrm{g} / \mathrm{ml})$. 


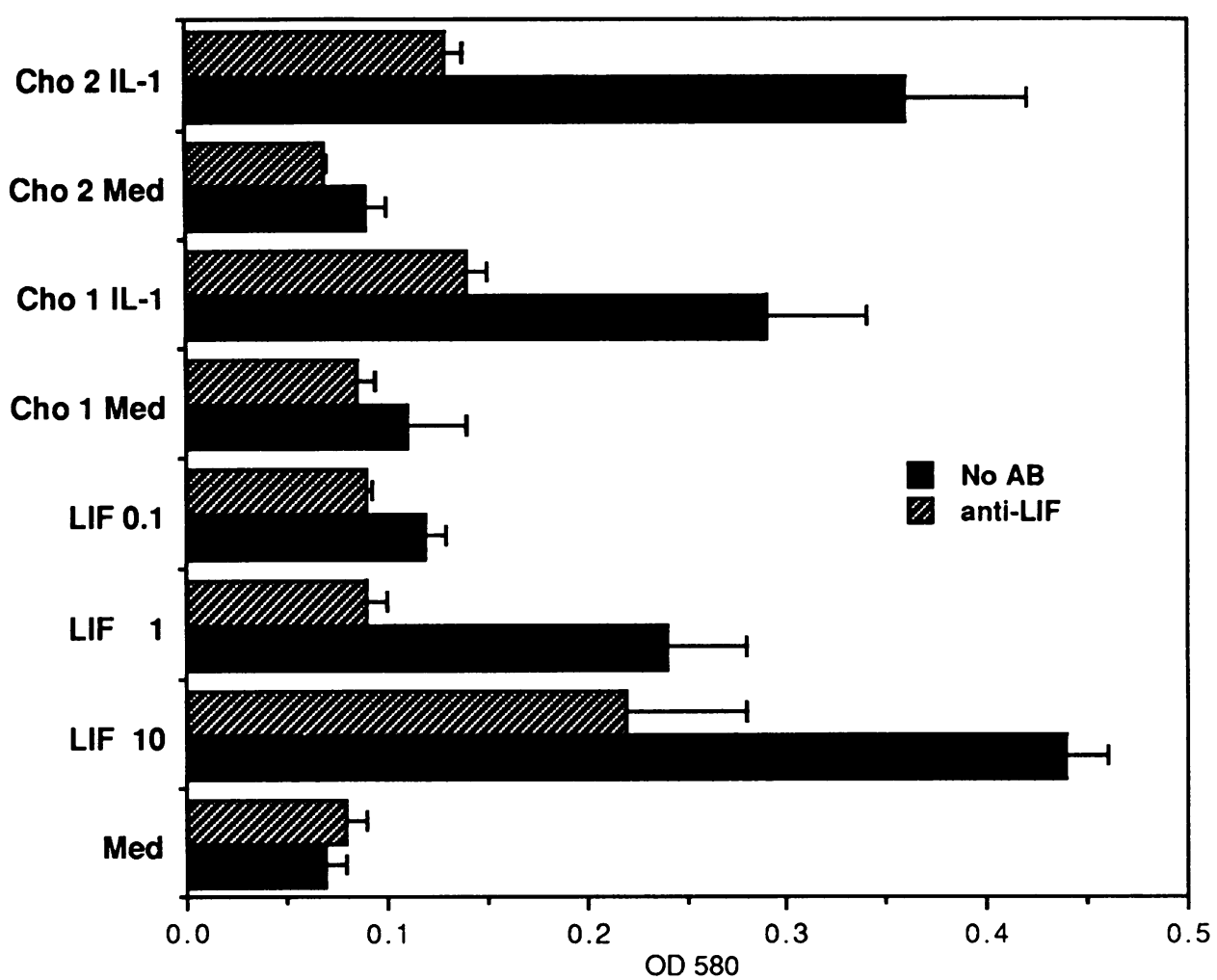

Figure 2. Secretion of LIF activity by human articular chondrocytes. Primary human articular chondrocytes were cultured in serum-free media for $24 \mathrm{~h}$ in the absence or presence of IL- $1 \beta(10 \mathrm{ng} / \mathrm{ml})$. Conditioned media were tested with or without neutralizing antibody to LIF $(10 \mu \mathrm{g} / \mathrm{ml})$ in the TF-1 proliferation assay. Each assay included a titration of recombinant human LIF $(\mathrm{ng} / \mathrm{ml})$. Proliferation of the cells was determined after $48 \mathrm{~h}$ by the MTT assay. ments the effects of recombinant peptide regulatory factors and other agents on the steady state levels of LIF mRNA were analyzed in serum-free media with cells that had been cultured in the absence of serum (serum-starved) for at least $16 \mathrm{~h}$.

We first tested the effects of IL- 1 and TGF $\beta$ on LIF mRNA levels. Receptors for IL- 1 and TGF- $\beta$ are known to be expressed on chondrocytes and these two factors induce qualitatively distinct responses in chondrocytes. Fig. 3 shows that both IL- $1 \beta$ and TGF $\beta$ caused a marked increase in LIF mRNA which was already detectable within $2 \mathrm{~h}$ of stimulation. The IL- $1 \beta$ effect was maximal by $5 \mathrm{~h}$, started to decline by $8 \mathrm{~h}$ and was no longer detectable by $11 \mathrm{~h}$. In contrast, the TGF- $\beta-$

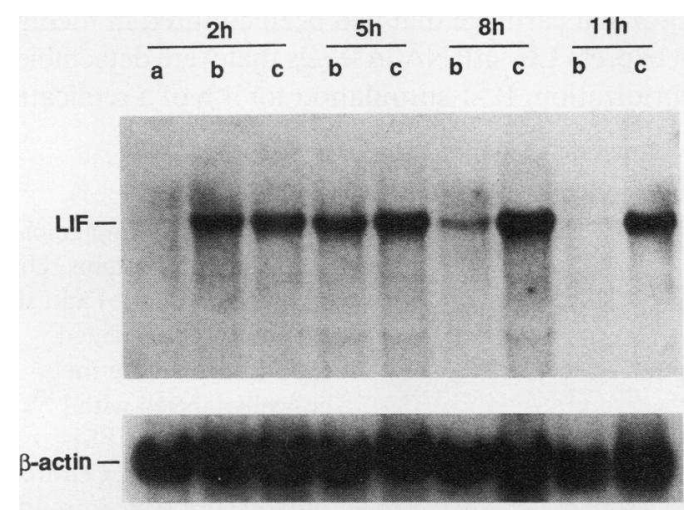

Figure 3. IL-1 $\beta$ and TGF $\beta$ increase LIF mRNA levels. Human articular chondrocytes ( from a newborn; passage 8) were serum starved and stimulated with IL- $1 \beta(10 \mathrm{ng} / \mathrm{ml})$ or TGF- $\beta_{1}(10 \mathrm{ng} / \mathrm{ml})$ for the time points indicated. Total cellular RNA was analyzed for LIF mRNA by Northern blotting. To assess equal load of mRNA per lane the filter was subsequently hybridized to a $\beta$-actin probe. ( $a$ ) Unstimulated; ( $b$ ) IL- $1 \beta ;$; $c$ ) TGF- $\beta$. mediated increase was prolonged and still apparent by $11 \mathrm{~h}$. The three isoforms TGF- $\beta_{1}$, TGF- $\beta_{2}$, and TGF $-\beta_{3}$ had similar effects on LIF mRNA levels. Dose-response studies showed that IL- $1 \beta$ caused a significant increase in LIF mRNA at 0.1 $\mathrm{ng} / \mathrm{ml}$ and maximal induction between 1 and $10 \mathrm{ng} / \mathrm{ml}$, which is the optimal concentration of most cytokines and growth factors for the induction of cytokines in chondrocytes and synoviocytes.

In addition to TGF- $\beta$, we analyzed several other chondrocyte growth factors, including bFGF, PDGF, and IGF-I, and found that they also caused a rapid increase in LIF mRNA (Fig. 4). However, the growth factors differed with respect to the duration of their effect. LIF mRNA levels in cultures treated with bFGF, PDGF, and IGF-I already started to decline by $5 \mathrm{~h}$ while the effects of TGF $\beta$ were still maximal at $8 \mathrm{~h}$.

Among other cytokines that are known to regulate chondrocyte function TNF $\alpha$ induced LIF mRNA while IL-6 showed a modest stimulatory effect. LPS also was a potent

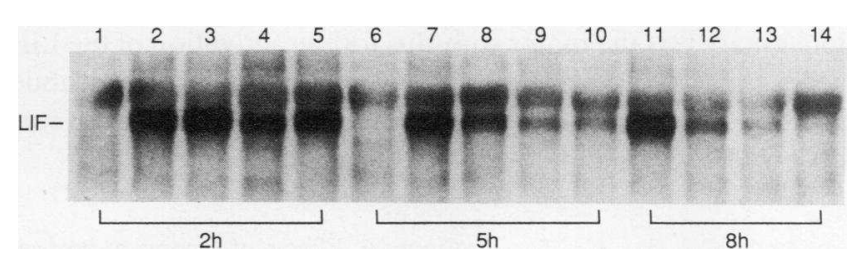

Figure 4. Chondrocyte growth factors and LIF gene expression. Human articular chondrocytes ( 73 yr old donor, passage 1) were stimulated with the different growth factors (all at $10 \mathrm{ng} / \mathrm{ml}$ ) for the time periods indicated. RNA was analyzed for the presence of LIF mRNA by Northern blotting. Equal RNA load was documented by ethidium bromide staining (not shown). Lanes 1,6 , unstimulated; lanes 1,7 , 11 , TGF- $\beta$; lanes $3,8,12$, PDGF; lanes $4,9,13$, bFGF; lanes 5,10 , 14, IGF-1. 


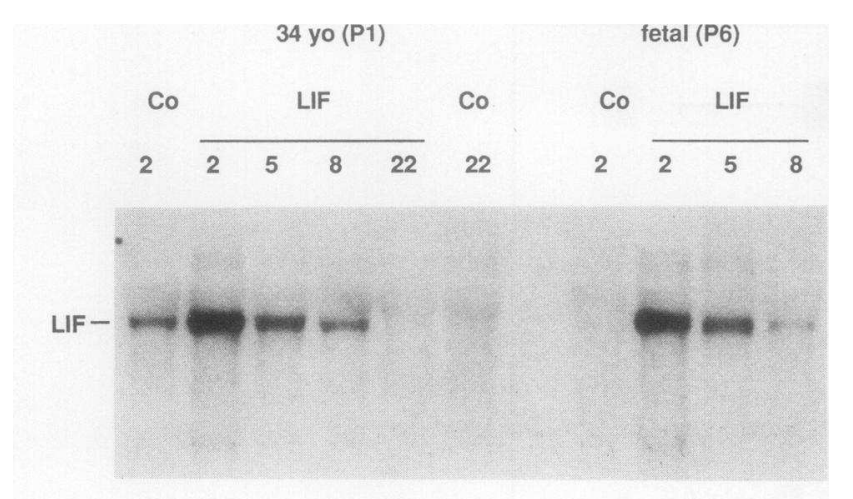

$\beta$-actin-

Figure 5. LIF autoinduction. Human articular chondrocytes (from a 30 -yr old donor, passage 2 and fetal chondrocytes, passage 6) were serum-starved and then stimulated with $\operatorname{LIF}(10 \mathrm{ng} / \mathrm{ml})$ for the time points indicated above the lanes. Total cellular RNA was extracted and analyzed for LIF mRNA by Northern blotting and RNA load was analyzed by probing for $\beta$-actin.

inducer of LIF mRNA expression in chondrocytes (not shown ). Several cytokines have the ability to increase the levels of their own mRNA. Fig. 5 shows two representative samples of fetal chondrocytes and cells from a 34 year old donor at early (P1) and late passage (P6). In both cell types LIF caused increased LIF mRNA expression. This was maximal already by 2 $\mathrm{h}$, declined by $8 \mathrm{~h}$, and returned to baseline between 8 and $22 \mathrm{~h}$. These results are the first demonstration of LIF autoinduction and represent evidence that this cytokine can regulate function of joint tissue cells.

Signal transduction pathways and induction of LIF gene expression. Only limited information is available on the signal transduction pathways that are involved with the induction of LIF. Fig. 6 shows that in chondrocytes activation of protein kinase $\mathrm{C}$ by phorbol ester provides a strong stimulus for the induction of LIF mRNA. In contrast, increases in the levels of intracellular calcium by the calcium ionophore A23187 and activation of protein kinase A by dibutyryl cAMP did not cause a detectable increase in LIF mRNA levels when applied as single stimuli or in combination with PMA.

Dexamethasone is a synthetic glucocorticoid which regulates cytokine expression. It profoundly inhibited LIF gene expression induced by PMA and IL- $1 \beta$ (Fig. 7). The protein synthesis inhibitor cycloheximide caused a strong increase in LIF mRNA (Fig. $7 \mathrm{~B}$ ). These results suggest that activation of protein kinase $C$ is the major stimulus for the activation of the LIF gene, and that it is under negative regulatory control by a labile protein. A similar pattern of LIF induction and inhibition was observed with rheumatoid synoviocytes (not shown).

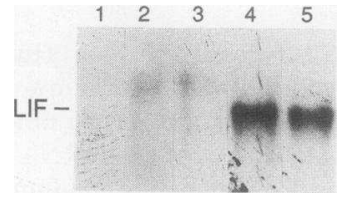

Figure 6. Effects of second messenger agonists on LIF gene expression. Rheumatoid arthritis synoviocytes (passage 4) were stimulated with CAMP $(250 \mu \mathrm{g} / \mathrm{ml})$, PMA (10 ng/ $\mathrm{ml})$ or calcium ionophore $\left(10^{-7} \mathrm{M}\right)$ for $4 \mathrm{~h}$. Results are from Northern blot on total RNA. Lane 1, unstimulated; lane 2, cAMP; lane 3, calcium ionophore; lane 4, PMA; lane 5, PMA + cAMP.
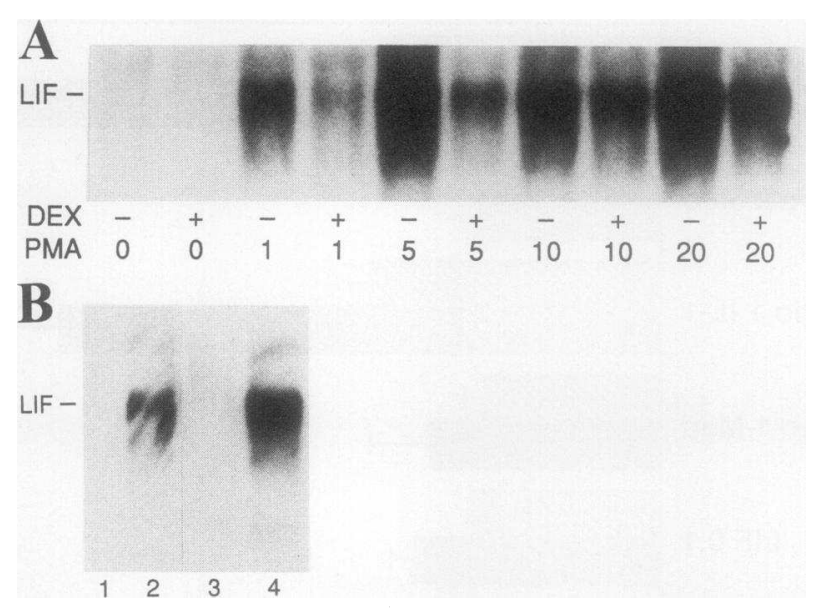

Figure 7. Regulation of LIF mRNA by dexamethasone and cycloheximide. ( $A$ ) Chondrocytes (from a 56-yr-old donor, passage 2 ) were cultured in the presence of PMA at the concentrations indicated $(\mathrm{ng} / \mathrm{ml})$ in the absence or presence of dexamethasone $\left(10^{-7} \mathrm{M}\right) .(B)$ Lane 1 , unstimulated; lane 2, IL- $1 \beta$; lane 3 , IL- $1 \beta+$ dexamethasone; lane 4 , cycloheximide $(50 \mu \mathrm{g} / \mathrm{ml}$ ) Cells were stimulated for $4 \mathrm{~h}$. LIF mRNA expression was analyzed by Northern blotting.

Characterization of LIF protein synthesis. To determine whether IL-1 stimulation of chondrocytes which leads to increased LIF mRNA and bioactivity is associated with a stimulation of LIF protein synthesis, chondrocytes were metabolically labeled and the secreted proteins were immunoprecipitated with a specific antiserum. Fig. 8 shows that supernatants from unstimulated cells contained very low levels of proteins that were recognized by the LIF-specific antiserum. Stimulation with IL-1 $\beta$ and PMA led to a marked increase in proteins that migrated as a broad band at $\sim 43 \mathrm{kD}$. This heterogeneity in LIF proteins is the likely result of differential glycosylation.

LIF gene expression in cartilage and synovial tissue organ cultures. The results presented above demonstrate that the LIF gene and proteins can be expressed by isolated synoviocytes and chondrocytes. Because these culture conditions remove the cells from their contact with extracellular matrix components and other cells, we analyzed the expression of LIF mRNA in cartilage and synovial tissue organ cultures.

Fig. 9 shows that cartilage that had been cultured in media alone did not express LIF mRNA in levels that were detectable by in situ hybridization. IL-1 stimulation for $4 \mathrm{~h}$ of a replicate

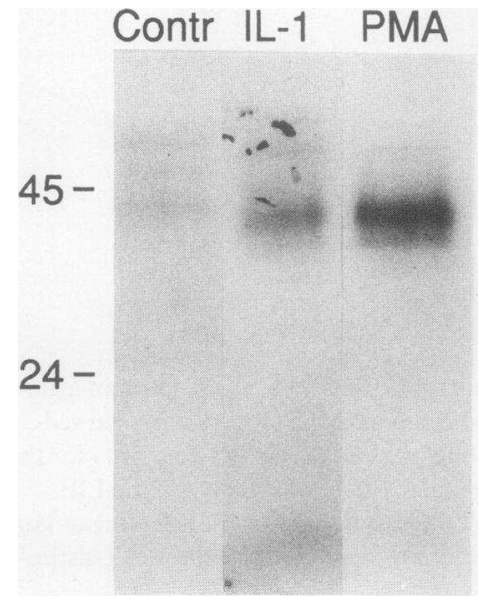

Figure 8. Immunoprecipitation of LIF proteins. Unstimulated (Contr.) and IL$1 \beta$ or PMA-stimulated chondrocytes were metabolically labeled with [ $\left.{ }^{35} \mathrm{~S}\right]-$ methionine and $\left[{ }^{35} \mathrm{~S}\right]-$ cysteine for $24 \mathrm{~h}$. Cell-free supernatants were immunoprecipitated with a rabbit antiserum against recombinant human LIF. The precipitates were separated on $12.5 \%$ SDS-PAGE and visualized by autoradiography. 

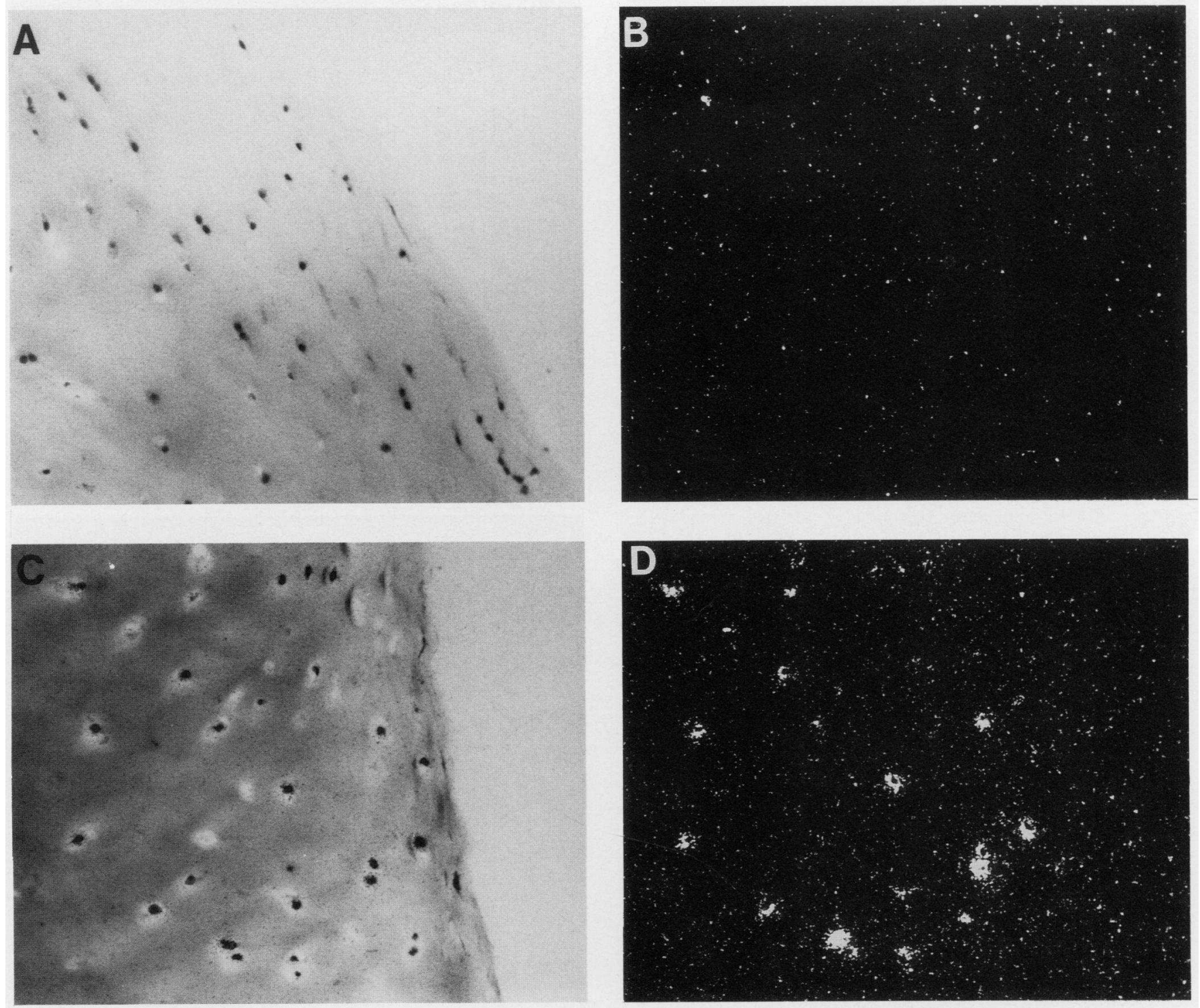

Figure 9. LIF gene expression in cartilage organ culture. Human articular cartilage stimulated with IL-1 $\beta(10 \mathrm{ng} / \mathrm{ml})$ for $4 \mathrm{~h}$. The tissue was embedded in OCT and frozen in liquid nitrogen. Frozen sections $(5 \mu \mathrm{m})$ were prepared and fixed with $4 \%$ paraformaldehyde. The sections were analyzed with a LIF anti-sense probe for LIF gene expression by in situ hybridization. $(A, B)$ unstimulated; $(C, D)$ IL-1 $\beta$-stimulated; $(A, C)$ bright field; $(B, D)$ dark field.

sample of the same cartilage specimen led to expression of readily detectable levels of LIF mRNA. Most of the cells expressed the LIF gene and positive cells were found throughout the different cartilage layers.

Rheumatoid synovial tissues contained LIF-positive cells that were scattered throughout the tissue and probably represent type A and/or type B synoviocytes (Fig. 10, $A$ and $B$ ). After stimulation with IL- $1 \beta$ for $4 \mathrm{~h}$, interstitial cells and cells associated with the vascular wall also expressed high levels of LIF mRNA. Hybridization of an adjacent section of the same tissue with a LIF sense probe was negative (Fig. 10, $C$ and $D$ ) and confirmed the specificity of the results obtained with the antisense probe. Having performed in situ hybridization on sections of unstimulated and IL- $1 \beta$-stimulated tissues, we then extracted RNA from the same samples and analyzed it by Northern blotting. This showed that cells in their natural environment also express 4.2-kb LIF mRNA in response to IL- $1 \beta$ (not shown) and provides further support for the specificity of the in situ hybridization studies.

\section{Discussion}

This study analyzed the expression of LIF by joint tissue cells. It is shown that synovial fluids from patients with arthritis contain biologically active LIF. Cultured chondrocytes and synoviocytes secrete LIF bioactivity and synthesize LIF proteins. The regulation of LIF gene expression by isolated cells, in cartilage organ culture and in synovial tissue, was examined. Inducers and inhibitors as well as signal transduction pathways that modulate LIF expression in synoviocytes and chondrocytes were characterized.

Studies on the regulation of connective tissue cells by peptide regulatory factors have provided detailed insight into the mechanisms that govern the expression of different functional 

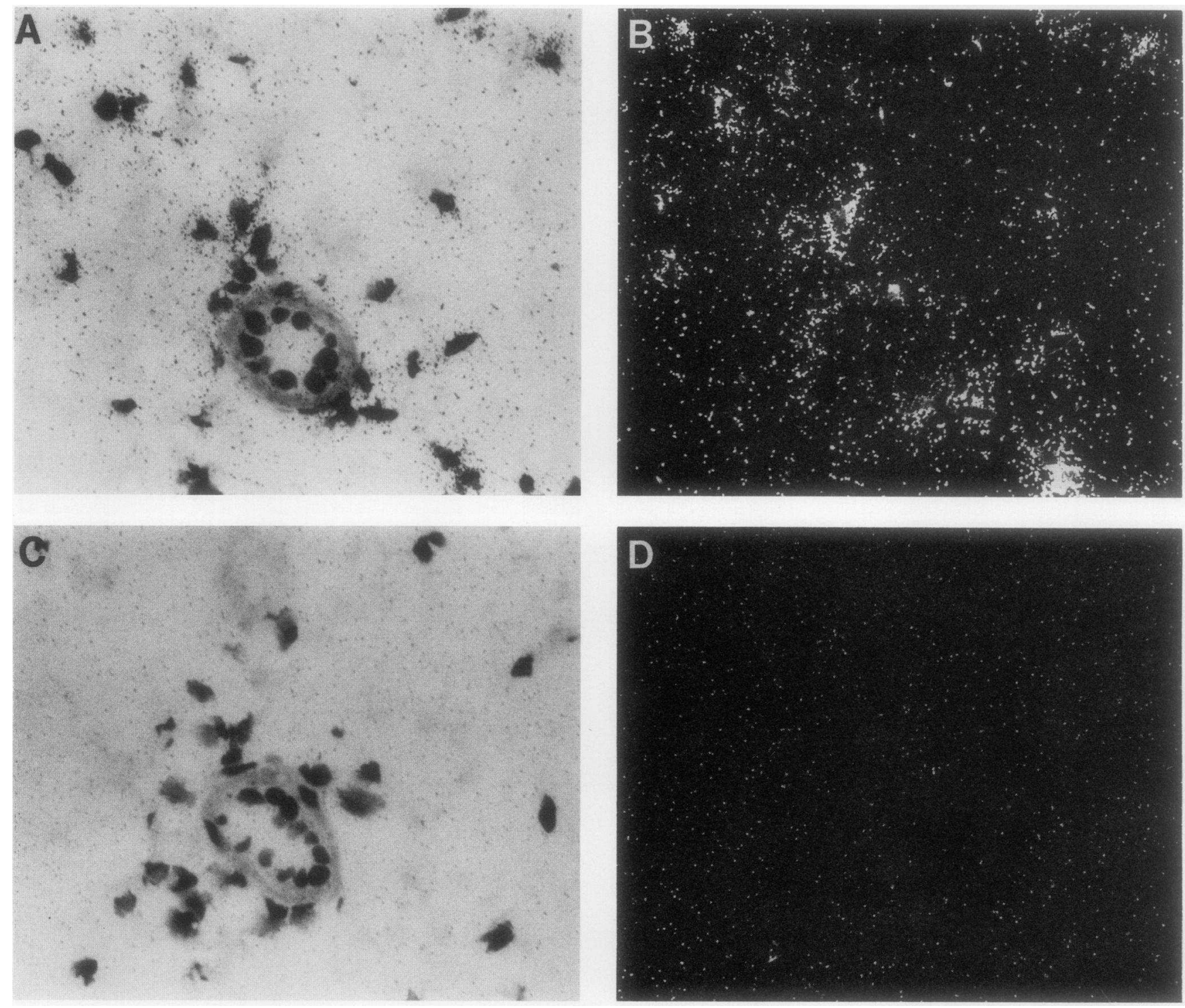

Figure 10. LIF gene expression in synovial tissue. Rheumatoid arthritis synovial tissue was stimulated with IL-1 $\beta(10 \mathrm{ng} / \mathrm{ml})$ for $4 \mathrm{~h}$. The tissue was embedded in OCT and frozen in liquid nitrogen. Frozen sections $(5 \mu \mathrm{m})$ were prepared and fixed with $4 \%$ paraformaldehyde. The sections were analyzed for LIF gene expression by in situ hybridization. All sections shown here are from IL- $1 \beta$-stimulated tissue. Unstimulated synovium was negative for LIF mRNA by in situ hybridization (not shown). $(A, B)$ LIF anti-sense probe; $(C, D)$ LIF sense probe; $(A, C)$ bright field; $(B, D)$ dark field.

programs in development, in responses to injury, and in the pathogenesis of a wide variety of acute and chronic inflammatory disorders that are associated with impaired connective tissue metabolism. Under physiological conditions such as during normal development and in wound healing qualitatively distinct phases of $(a)$ inflammation and protease-mediated connective tissue resorption, $(b)$ inhibition of the expression and function of proteases, and $(c)$ connective tissue cell proliferation and the formation of organ-specific connective tissue can be distinguished. All of these phases are functions of resident connective tissue cells and infiltrating inflammatory cells that are under regulatory control by cytokines, growth factors, and neuropeptides. Although there is some redundancy and overlap between the effects of these peptide regulatory factors on :connective tissue cells, they can be classified into groups that include catabolic factors which stimulate the production of proteases and inhibit formation of extracellular matrix, inducers of protease inhibitors, growth factors, and anabolic factors that stimulate the production of extracellular matrix. Among the cytokines, IL-1 and TNF are the principal catabolic factors (4). IL-6 induces protease inhibitors systemically and locally in the extravascular space but it does not induce the production of proteases or $\mathrm{PGE}_{2}$ (5-8). IL-8 and MCP-1 are produced by activated connective tissue cells but they appear to be predominantly responsible for the recruitment of inflammatory cells and have probably no direct effect on connective tissue cells (10).

LIF is a more recently identified cytokine which regulates function of a variety of different cell types $(20,21)$. The present study shows that LIF activity can be detected in synovial fluids from patients with arthritis. LIF activity was measured with a cell line that is sensitive to growth stimulation by other 
cytokines (40). With this assay we were able to clearly demonstrate the presence of LIF in synovial fluids. Because of the limitations of this assay, a large survey of sera and synovial fluids for LIF was not feasible. Chondrocytes and synoviocytes both have the ability to secrete biologically active LIF in response to activation by IL-1 or PMA. In immunoprecipitation studies LIF appears as heterogeneous group of proteins with a molecular mass of $\sim 43 \mathrm{kD}$. The unglycosylated factor has a predicted molecular mass of $\sim 20 \mathrm{kD}$. LIF has multiple potential glycosylation sites and the molecular mass of chondrocytederived LIF and its heterogeneity are probably due to differential glycosylation.

Chondrocytes and synoviocytes expressed LIF mRNA at the expected size of $4.2 \mathrm{~kb}(41)$. The LIF gene was readily inducible by cytokines and growth factors that are known to act on joint tissue cells. IL- $1 \beta$ was the most potent cytokine for LIF induction. TNF was weaker but still induced LIF mRNA and IL-6 had only a marginal effect. LIF induced its own mRNA which may represent a mechanism to amplify the initial stimulus of LIF induction. LIF is thus inducible in joint tissue cells by a similar set of cytokines as IL-6, IL-8, and MCP-1 (15, $18,19)$.

All of the major chondrocyte growth factors increased LIF mRNA levels but with different time kinetics. In response to all agents there was a rapid increase that was detectable after $2 \mathrm{~h}$. TGF $\beta$ caused the most prolonged elevation in LIF mRNA as compared to the other growth factors and cytokines. These distinct kinetics suggest that various growth factors may utilize different mechanisms for the induction of LIF.

There is only limited information on the signal transduction mechanisms that lead to LIF expression. Previous studies had shown that activation of protein kinase $C$ by phorbol esters can induce LIF mRNA $(42,43)$. We show that this occurs in chondrocytes where PMA also stimulated LIF protein synthesis.

This study also shows that activation of protein kinase A and elevation of intracellular calcium alone or in combination with PMA does not induce LIF in chondrocytes or synoviocytes. Furthermore, cycloheximide caused a marked induction of the LIF gene. The effect of cycloheximide was detectable under conditions where there was no constitutive LIF mRNA expression as analyzed by Northern blotting. These results suggest that LIF mRNA levels are at least in part regulated by a labile protein that inhibits transcription or acts postranscriptionally to prevent the accumulation of mature LIF mRNA. Dexamethasone is a potent inhibitor of LIF expression in response to IL- $1 \beta$ or PMA. This finding is consistent with the notion that activation of the protein kinase $C$ is probably the major stimulus for the induction of LIF.

LIF produced by joint tissue cells can contribute to several manifestations of arthritis. Bone resorption is a feature of RA and at least in some experimental systems this is stimulated by LIF (32-37). IL-6 is considered to be a major hepatocyte stimulating factor (7) that induces the production of several acute phase proteins that are increased in the serum of patients with arthritis and are used as markers of disease activity. LIF stimulates the production of a similar set of acute phase proteins (30). The effects of LIF on bone-marrow-derived cells include the stimulation of marrow blasts (25) and megakaryocytes (26). Based on its expression by joint tissue cells and its presence in joint fluids LIF thus has the potential to contribute to the hepatic acute-phase response, leukocytosis, and thrombo- cytosis which are often seen in patients with active arthritis. As shown here, LIF increases its own mRNA levels. In addition, LIF also enhances the expression of other cytokines including IL-6, MCP-1, and IL-8 (in preparation). With this property LIF can indirectly stimulate connective tissue cells. Probably more important to connective tissue metabolism are the direct effects of LIF on chondrocytes and synoviocytes. In addition to the induction of other cytokines, we have recently shown that LIF also stimulates the production of the metalloproteinases stromelysin and collagenase (manuscript in preparation). With the induction of other cytokines and of metalloproteinases and the possible inhibition of extracellular matrix synthesis (37) LIF can be characterized as a catabolic cytokine that is qualitatively similar to IL-1 and TNF in its effects on joint tissue cells.

In conclusion, LIF is produced by synoviocytes and chondrocytes and it is present in synovial fluids. Its effects on connective tissue cells characterize it as a catabolic factor that is qualitatively similar to IL-1 and TNF. This cytokine represents a new member of the group factors that are overexpressed in arthritis, induce connective tissue degradation and may contribute to systemic manifestations of arthritis.

\section{Acknowledgments}

Jacqueline Quach provided expert technical assistance. We thank Drs. R. D. Coutts, K. Benirschke, and C. Colwell for providing cartilage and synovial tissue.

This work was supported by National Institutes of Health grants AG07996 and AR39799 and by a grant from the Office of Naval Research (ONR N00014-90-J-1637).

\section{References}

1. Mizel, S. B., J. M. Dayer, S. M. Krane, and S. E. Mergenhagen. 1981. Stimulation of rheumatoid synovial cell collagenase and prostaglandin production by partially purified lymphocyte activating factor (interleukin-1). Proc. Natl. Acad. Sci. USA. 78:2474-2477.

2. Dayer, J. M., B. Beutler, and A. Cerami. 1985. Cachectin/tumor necrosis factor stimulates collagenase and prostaglandin $E_{2}$ production by human synovial cells and dermal fibroblasts. J. Exp. Med. 162:2163-2168.

3. Saklatvala, J. 1986. Tumor necrosis factor alpha stimulates resorption and inhibits synthesis of proteoglycan in culture. Nature (Lond.). 322:547-549.

4. Le, J., and J. Vilcek. 1987. Tumor necrosis factor and Interleukin-1. Lab. Invest. 56:234-248.

5. Kishimoto, T. 1989. Interleukin-6. Blood. 74:1-10.

6. Lotz, M., and P.-A. Guerne. 1991. Interleukin-6 induces the synthesis of tissue inhibitor of metallo-proteinases-1/erythroid potentiating activity (TIMP1/EPA). J. Biol. Chem. 266:2017-2020.

7. Gauldie, J., C. Richards, D. Harnish, P. Lansdorp, and H. Baumann. 1987. Interferon $\beta 2$ / B cell stimulator factor- 2 shares identity with hepatocyte stimulating factor and regulates the major acute phase protein response in liver cells. Proc. Natl. Acad. Sci. USA. 84:7251-7255.

8. Zuraw, B. L., and M. Lotz. 1990. Regulation of the hepatic synthesis of C1 inhibitor by the hepatocyte stimulating factors interleukin- 6 and interferon $\gamma$. J. Biol. Chem. 265:12664-12670.

9. Guerne, P.-A., and M. Lotz. 1991. Regulation of Swarm rat chondrosarcoma cell proliferation: synergy between interleukin-6 (IL-6) and transforming growth factor- $\beta$ (TGF $\beta$ ). J. Cell. Physiol. 149:117-124.

10. Oppenheim, J. J., C. O. C. Zacharie, N. Mukaida, and K. Matsushima. 1991. Properties of the novel proinflammatory supergene "intercrine" cytokine family. Annu. Rev. Immunol. 9:617-648.

11. Wood, D. D., E. J. Ihrie, C. A. Dinarello, and P. L. Cohen. 1983. Isolation of an interleukin-1-like activity from human joint effusions. Arthritis Rheum. 31:1041-1045.

12. Saxne, T., M. A. Palladino, Jr., D. Heinegard, N. Talal, and F. A. Wollheim. 1988. Detection of tumor necrosis factor $\alpha$ but not tumor necrosis factor $\beta$ in rheumatoid arthritis synovial fluid and serum. Arthritis Rheum. 31:10411045.

13. Fava, R., N. Olsen, J. Keski-Oja, H. Moses, and T. Pincus. 1989. Active 
and latent forms of transforming growth factor $\beta$ in synovial effusions. J. Exp. Med. 169:291-296.

14. Lotz, M., J. Kekow, and D. A. Carson. 1990. Transforming growth factor$\beta$ and cellular immune responses in synovial fluid. J. Immunol. 144:4189-4194.

15. Guerne, P.-A., B. L. Zuraw, J. H. Vaughan, D. A. Carson, and M. Lotz 1989. Synovium as a source of interleukin-6 in vitro: contribution to local and systemic manifestations of arthritis. J. Clin. Invest. 83:585-592.

16. Firestein, G. S., W. D. Xu, K. Townsend, D. Brodie, J. Alvaro-Garcia, A Glasebrook, and N. J. Zvaifler. 1988. Cytokines in chronic inflammatory arthritis. I. Failure to detect $T$ cell lymphokines (interleukin-2 and interleukin-3) and presence of macrophage colony stimulating factor (CSF-1) and novel mast cell growth factor in rheumatoid synovitis. J. Exp. Med. 168:1573-1586.

17. Seitz, M., B. Dewald, N. Gerber, and M. Baggiolini. 1991. Enhanced production of neutrophil-activating peptide-1/interleukin-8 in rheumatoid arthritis. J. Clin. Invest. 87:463-469.

18. Lotz, M., R. Terkeltaub, and P. Villiger. 1992. Cartilage and joint inflammation: expression of IL-8 in response to peptide regulatory factors and proinflammatory agents. J. Immunol. 148:466-473.

19. Villiger, P., R. Terkeltaub, and M. Lotz. 1992. Monocyte chemoattractant protein-1 (MCP-1) expression in human articular cartilage: induction by peptide regulatory factors and differential effects of dexamethasone and retinoic acid. $J$. Clin. Invest. 90:488-496.

20. Gearing, D. P. 1990. Leukemia inhibitory factor: does the cap fit? Ann N.Y. Acad. Sci. 628:9-18

21. Metcalf, D. 1991. The leukemia inhibitory factor (LIF). Int. J. Cell Cloning. 9:95-108.

22. Metcalf, D., D. J. Hilton, and N. A. Nicola. 1988. Clonal analysis of the actions of the murine leukemia inhibitory factor on leukaemic and normal murine haematopoietic cells. Leukemia. 2:216-221.

23. Moreau, J. F., D. D. Donaldson, F. Bennett, J. Witek-Giannotti, S. C. Clark, and G. G. Wong. 1988. Leukaemia inhibitory factor is identical to the myeloid growth factor human interleukin for DA cells. Nature (Lond.). 336:690692.

24. Abe, T., M. Murakami, T. Sato, M. Kajiki, M. Ohno, and R. Kodaira. 1989. Macrophage differentiation inducing factor from human monocytic cells is equivalent to murine leukemia inhibitory factor. J. Biol. Chem. 264:8941-8945.

25. Verfaillie, C., and P. McGlave. 1991. Leukemia inhibitory factor/human interleukin for DA cells: a growth factor that stimulates the in vitro development of multipotential human hematopoietic progenitors. Blood. 77:263-270.

26. Metcalf, D., D. Hilton, and N. A. Nicola. 1991. Leukemia inhibitory factor can potentiate murine megakaryocyte production in vitro. Blood. 77:2150-2153.

27. Smith, A. G., J. K. Heath, D. D. Donaldson, G. G. Wong, J. Moreau, M Stahl, and D. Rogers. 1988. Inhibition of pluripotential embryonic stem cell differentiation by purified polypeptides. Nature (Lond.). 336:688-690.

28. Murphy, M. K. Reid, D. J. Hilton, and P. F. Bartlett. 1991. Generation of sensory neurons is stimulated by leukemia inhibitory factor. Proc. Natl. Acad. Sci. USA. 88:3498-3501.

29. Yamamori, T., K. Fukada, R. Aebersold, S. Korsching, M. J. Fann, and P. H. Patterson. 1989. The cholinergic neuronal differentiation factor from heart cells is identical to leukemia inhibitory factor. Science (Wash. DC). 246:14121416.

30. Baumann, H., and G. G. Wong. 1989. Hepatocyte-stimulating factor III shares structural and functional identity with leukemia-inhibitory factor. $J$. Immunol. 143:1163-1167.

31. Mori, M., K. Yamaguchi, and K. Abe. 1989. Purification of a lipoprotein lipase-inhibiting protein produced by a melanoma cell line associated with cancer cachexia. Biochem. Biophys. Res. Commun. 160:1085-1092.

32. Metcalf, D., and D. P. Gearing. 1989. Fatal syndrome in mice engrafted with cells producing high levels of the leukemia inhibitory factor. Proc. Natl. Acad. Sci. USA. 86:5948-5952.

33. Metcalf, D., and D. P. Gearing. 1989. A myelosclerotic syndrome in mice engrafted with cells producing high levels of leukemia inhibitory factor. Leukemia. 12:847-852.

34. Reid, L. R., C. Lowe, J. Cornish, S. J. Skinner, D. J. Hilton, T. A. Wilson, D. P. Gearing, and T. J. Martin. 1990. Leukemia inhibitory factor: a novel boneactive cytokine. Endocrinology. 126:1416-1420.

35. Rodan, S. B., G. Wesolowski, D. J. Hilton, N. A. Nicola, and G. A. Rodan. 1990. Leukemia inhibitory factor binds with high affinity to preosteoblastic RCT 1 cells and potentiates the retinoic acid induction of alkaline phosphatase. Endocrinology. 127:1602-1608.

36. Allan, E. H., D. J. Hilton, M. A. Brown, R. S. Evely, S. Yumita, D. Metcalf, N. M. Gough, K. W. Ng, N. A. Nicola, and T. J. Martin. 1990. Osteoblasts display receptors for and responses to leukemia inhibitory factor. J. Cell. Physiol. 145:110-119.

37. Noda, M., R. L. Vogel, D. M. Hasson, and G. A. Rodan. 1990. Leukemia inhibitory factor suppresses proliferation, alkaline phosphatase activity, and type I collagen messenger ribonucleic acid level and enhances osteopontin mRNA level in murine osteoblast-like (MC3T3E1) cells. Endocrinology. 127:185-190.

38. Chomczynski, P., and N. Sacchi. 1987. Single-step method of RNA isolation by acid guanidinium thiocyanate-phenol-chloroform extraction. Anal. Biochem. 162:156-159.

39. Villiger, P., M. T. Cronin, T. Amenomori, W. Wachsman, and M. Lotz. 1991. IL-6 production by human T cells: expression by HTLV-1 infected nut not in normal T cells. J. Immunol. 146:550-559.

40. Kitamura, T., T. Tange, T. Terasawa, S. Chiba, T. Kuwaki, K. Miyagawa, Y. F. Piao, K. Miyazono, A. Urabe, and F. Takaku. 1989. Establishment of human cell line that proliferates dependently on GM-CSF, IL-3 or erythropoietin. J. Cell. Physiol. 140:323-334.

41. Stahl, J., D. P. Gearing, T. A. Willson, M. A. Brown, J. A. King, and G. M. Gough. 1990. Structural organization of the genes for murine and human leukemia inhibitory factor: evolutionary conservation of coding and non-coding regions. J. Biol. Chem. 265:8833-8841.

42. Lubbert, M., L. Mantovani, A. Lindemann, R. Mertelsmann, and F. Herrmann. 1991. Expression of leukemia inhibitory factor is regulated in human mesenchymal cells. Leukemia. 5:361-365.

43. Anegon, I., J. F. Moreau, A. Godard, Y. Jacques, M. A. Peyrat, M. M. Hallet, G. Wong, and J. P. Soulillou. 1990. Production of human interleukin for DA cells (HILDA)/leukemia inhibitory factor (LIF) by activated monocytes. Cell. Immunol. 130:50-65. 